\title{
The Value of Ho Chi Minh's Ideology, Morality and Style to the Vietnamese Nation Today
}

\author{
Le Trung Kien ${ }^{1}$ \\ ${ }^{1}$ The Institute of Ho Chi Minh and Party leaders, Ho Chi Minh National Academy of Politics, Hanoi, Vietnam \\ Correspondence: 135 Nguyen Phong Sac, Cau Giay, Ha Noi, Vietnam. Tel: 084-9-7187-2888. E-mail: \\ kienlt1511@gmail.com
}

Received: August 4, 2021

Accepted: September 7, 2021

Online Published: September 9, 2021

doi:10.5539/jpl.v14n4p126

URL: https://doi.org/10.5539/jpl.v14n4p126

\begin{abstract}
This article aims to clarify the basic contents of leader Ho Chi Minh's ideology, morality and style that are valuable to the Vietnamese nation. In fact, Vietnam has been proving the miraculous vitality of Ho Chi Minh's ideology on the path and goals of national development, on the strategy of great national unity and international solidarity, innovative thinking, culture and humanities. His moral example and views on revolutionary ethical standards and ethical practice principles are the red thread throughout the progress of progressive and civilized human development. His style is extremely lively, natural, unique, attractive, magical in daily activities and behavior, which is shown as independent, self-directed and creative thinking style; scientific, democratic and mass working style; modest, polite, sincere, warm, natural and flexible behavior style; simple, clean, moderate, moderate living style. These legacies form a consistent whole in Ho Chi Minh's people, have deep scientific, theoretical and practical values in terms of ethics and aesthetics, consistent with the history of the Vietnamese nation and the development trend of mankind.
\end{abstract}

Keywords: ideology, morality, style, Ho Chi Minh

\section{Introduction}

Ho Chi Minh (May 19, 1890 - September 2, 1969) is known to the world as the leader that Vietnamese people often call Bac Ho, UNESCO honors Him as an outstanding cultural celebrity, hero of national liberation. He was born in Nghe An (Central of Vietnam), grew up and witnessed the scene of "lost country, broken house", with passionate patriotism, in 1911, he went to the West to find a way to liberate the nation; in 1930, he become the Chairman of the Founding Conference of the Communist Party of Vietnam (CPV) in Huong Cang (now Hong Kong, China); Until 1941, He returned home to directly lead the Vietnamese revolution until His death. His life had to travel about 30 countries and territories, 2 times in prison and a death sentence in His absence, but He overcame all hardships, was steadfast and ready to sacrifice and lead the Vietnamese people to victory in the struggle against colonialism and imperialism to bring independence, freedom and happiness to the Vietnamese people and to move towards building socialism. He has 175 names, pseudonyms and thousands of articles and speeches collected in Ho Chi Minh Complete Volume, including 15 volumes published in 2021. Currently, there are many comprehensive research works on Ho Chi Minh's science, which mainly Vietnam and a number of foreign scholars have published works on Ho Chi Minh's ideology, life and activities. The ideological, moral and stylistic legacies of Ho Chi Minh are the product of a skillful combination between the fine traditional values of the Vietnamese nation, the quintessence of human culture and His personal qualities, converged and created a unified whole in Ho Chi Minh, having sustainable values and symbolic meaning of enlightening the civilized Vietnamese nation and becoming the cultural value system of mankind. Assessing Ho Chi Minh's merits for the development and progress of humanity, Dr. Modagat Ahmet - Director of UNESCO Asia - Pacific region, emphasized: "There are only a few figures in history who became part of the legend during their lifetime and Ho Chi Minh is clearly one of them. He will be remembered not only as the liberator of the colonized Fatherland and the people, but also as a modern sage who brought a new perspective and hope for those who are fighting mercilessly to remove injustice and inequality from the world". (NCSH, 1995, p. 28-29).

\section{Methodology}

The article is based on a dialectical materialism stance, applying a comprehensive and systematic perspective, ensuring the principles of inheritance and development, and linking theory with practice. The article uses a 
combination of scientific methods, namely: historical and generalization method, logical and comparative method, exemplary method, analysis method and statistics method... to clarify each content of Ho Chi Minh's ideology, morality and style that is valuable to the Vietnamese nation today.

\section{Results}

\subsection{The Sustainable Value of Ho Chi Minh's Thought for the Vietnamese Nation}

Firstly, on the path and goal of the nation's independence, freedom and happiness.

In his life, the available qualities combined with the rich and lively practical activities of Ho Chi Minh became an important basis in choosing the path of independence, freedom and happiness for the Vietnamese nation. His non-stop activities have maximized independent, autonomous and creative thinking to find out the laws of perception and action, generalized into theory, tested in practice which He became a great leader to locate the development path for the Vietnamese nation today. Therefore, a French journalist wrote: "Bac Ho's strange career is not in His ideological dimension... He is just a genius controller, a genius skillful man, a structural communist because of having spent his life building, molding, and creating the movement" (Lacouture, 1967, p. 200 ).

On June 5, 1911, He took the name Van Ba, boarded the Amiral Latouche-Tréville ship to leave Nha Rong harbor (Ho Chi Minh City, Vietnam) to Marseille (France), carrying in Him patriotism and love for the people, embracing a great ambition: learning about Western civilization, learning to return to help the Vietnamese people. Therefore, answering American writer Aana Luy Xotorong, He said: "I feel I have to go abroad to see clearly. After seeing how they do business, I will return to help my people" (Nhan Dan Newspaper, 1965). On June 18, 1919, on behalf of the Association of Vietnamese patriots in France and the UK, He took the name Nguyen Ai Quoc (ie Patriotic Nguyen) and sent to the Versailles Conference (Conference of the victorious Allies after World War I) the Vietnamese people's Claim demanding that the French government recognize the freedom, democracy and equal rights of the Vietnamese people but it was not accepted by the authorities; This action caused a great resonance in public opinion in France and around the world. "From the day Nguyen Ai Quoc sent a claim to the Conference, overseas Vietnamese turned to Him..., overseas Vietnamese came to Nguyen Ai Quoc for His advice, to be assigned tasks and outlined which way to follow. So from Paris, Nguyen Ai Quoc planted the seeds of revolution in the four corners of the earth" (Charles Fourniaux, 1970, p. 29).

In the flow of the world revolution with many different trends, but with His intellectual capital and scientific thinking, he affirmed that only Marxism-Leninism is the manual, the theory that guides the Vietnamese revolution to complete victory. Looking back on this event, in 1960, He wrote: "Personally, from the beginning, thanks to studying the glorious revolutionary tradition and being trained in the reality of the heroic struggle of the workers and of the French Communist Party, I have found the truth of Marxism-Leninism, turned from a progressive patriot to a socialist soldier" (Ho Chi Minh, 2021, vol. 12, p. 740). But He added to the theory of the classics of Marx, Engels and Lenin in the assessment that: "President Ho Chi Minh's analysis of colonialism up to that time surpassed all which Marxist theorists mentioned. President Ho Chi Minh has built up a synthesis of theories of liberation from colonial oppression, which has undeniable power" (Ginbe Handatso, 1970). He did all he could to spread Marxism-Leninism and actively prepared politically, ideologically and organizationally for the birth of a proletarian political party in Vietnam. Through each turning point, each revolutionary step, since the birth of CPV, He has always affirmed: "Consistently and constantly applying and creatively developing Marxism-Leninism, Ho Chi Minh's ideology is consistent with Vietnamese practice in each period" (CPV, 2021, vol. 1, p. 180).

In the spirit of self-reliance and creativity, He raised the level of thinking about human rights and civil rights that the bourgeoisie talked about in the American Declaration of Independence (1776) and the French Declaration of the Rights of Man and the Citizen (1791) to affirm the value for humanity that "all nations in the world have the right to be equal, to live, to be happy and to be free" (Ho Chi Minh, 2021, vol. 11, p. 285). And when He found the revolutionary path and the theory that leads the way, He made every effort to realize the liberation and develop the country into a rich, strong, democratic, fair and civilized Vietnam.

Secondly, on the strategy of great national unity and international solidarity.

For Ho Chi Minh, loving the people, believing in the people, respecting the people, respecting the people, being close to the people, for the people's happiness is the supreme principle. This principle is both a continuation of the national tradition of "Taking people as the roots" and at the same time a profound understanding of the principle that "the revolution is the cause of the masses". The people are the solid support of the leading political organization, the source of invincible and inexhaustible strength of the great unity bloc, and the decisive victory of 
the revolution. He pointed out: "Great unity means first of all to unite the vast majority of the people, of which the vast majority of our people are workers, farmers and other working classes. That is the foundation of great unity. It is like the foundation of the house, the root of the tree" (Ho Chi Minh, 2021, vol. 9, p. 244).

Great national unity is a matter of strategic significance, deciding the success of the revolution. He always implements the motto: "Unity, unity, great unity, Success, success, great success" (Ho Chi Minh, 2021, vol. 13, p. 119). Great national unity is the nation's top goal and task. Because revolution is the cause of the people, by the people, for the people. CPV has the mission of awakening, gathering, guiding the masses, transforming the needs and demands of independence, freedom and happiness into reality in the great national unity bloc. He often reminded those in power to be imbued with the teaching that "Without people, easy jobs are difficult to do, with people, difficult jobs are easy to do". Realizing international solidarity is to gather external forces, enlist the consensus, support and help of international friends, combining national strength with the strength of the times, to form a synergy for the revolutionary cause. "In Canada, the International Days of Protest marked the first coordinated nation-wide protests against the war in Vietnam, with many local antiwar groups taking on the name of Vietnam Day Committee or the Committee to End the War in Vietnam. The International Days of Protest to End the War in Vietnam also initiated increasing participation in the antiwar movement by members of trade unions. The entry of organized labour into the movement in Canada significantly preceded any substantial antiwar activity by unions in the United States" (Christopher William Powell, 2010, p. 133). Ho Chi Minh said: "With the strength of the whole country with one heart... and with the support of the people of the world, we will have a synergy plus an appropriate revolutionary method, surely our country's revolution will reach its final destination" (Ha Binh Nhuong, 2000, p. 20).

International solidarity on the basis of unity for interests, being reasonable and being emotional. "Being reasonable" must first come from the common interests of each nation and the world; The interests of each country, nation, and party must be respected, but such interests must not be detrimental to the common interests of other parties or other peoples. "Being emotional" is understanding and respecting each other in the spirit and affection of people who share the same ideals and goals; must overcome the ideology of Chauvinism, "big country", "big party"; do not "impose", "inhibit", slander, openly attack each other, or use political and economic solutions... to pressure each other. In 1947, answering journalist S. Elie Maissie, a reporter for the International News Service (INS) of the United States, Ho Chi Minh declared: Vietnam's foreign policy is to "make friends with all democracies and hold no enmity with anyone" (Ho Chi Minh, 2021, vol. 5, p. 256). Evaluating Ho Chi Minh's role and contributions in building the unity bloc, the President of the World Peace Council said: "Wherever fighting for independence and freedom, there is Ho Chi Minh and the flag of Ho Chi Minh is flying high. Wherever fighting for peace and justice, there is Ho Chi Minh and the flag of Ho Chi Minh is flying high. Wherever people fight for a new world, against hunger and poverty, the flag of Ho Chi Minh is flying high" (Romesh Chandra, 1980). Raising the flag of peace and fighting to protect true peace for the fundamental national rights of each country is the immutable thought of Ho Chi Minh.

Thirdly, on innovative thinking in Vietnam.

Ho Chi Minh's ideology on innovation is a system of oriented views, comprehensively changing the old with the new and progressive in order to apply new forms and new models to the condition of a backward and underdeveloped Vietnam with the goal of building the country into an independent, self-reliant, advanced country, developing side by side with the great powers of the five continents. This is a long, difficult, complex and comprehensive process in all fields, requiring very high political responsibility of the CPV and the nation.

New thinking on social organizations and institutions must first have a revolutionary leadership organization. He wrote: "What must the revolution have first? First of all, there must be a revolutionary party, in order to mobilize and organize the people inside, and to communicate with the oppressed nation and the class proletariat everywhere outside. If the Party is solid, the revolution will succeed, just as the experienced helmsman can control the boat" (Ho Chi Minh, 2021, vol. 2, p. 289). The emergence of a new type of party in Vietnam comes from the process of properly perceiving the theory of the birth law of the CPV which is the combination of Marxism - Leninism with the workers' movement and the Vietnamese patriotic movement. He clearly spoke about the nature, nature of class, the people's character and the ethnicity of CPV. CPV's responsibility is to have ready, clear and thoughtful lines, directives, resolutions and plans "to avoid passivity, omissions and mistakes". The Party must be truly "clean", "united" and "pure from big to small works" (Ho Chi Minh, 2021, vol. 5, p. 75) to be able to lead the people and the revolution for "complete victory".

New thinking on economic development is based on the theory of the times and affirms the necessity of the progress of human society. "There is no force that can stop the sun from rising. There is no force that can stop 
human history from moving forward" (Ho Chi Minh, 2021, vol. 11, p. 158). During His lifetime, He always attached great importance to the role of productive forces, appropriate production relations, economic factors, and beneficial motives for development. He paid special attention to and made efforts to liberate the labor force in order to create an important impetus in building socialism. He focused on ensuring fairness in the distribution of benefits based on the principle: "Those who work a lot enjoy a lot, those who work a little enjoy little, those who don't work get no benefits, except of course the elderly, sick and children" (Ho Chi Minh, 2021, vol. 10, p. 390).

Industrialization is an inevitable trend for sustainable economic development, contributing to promoting the development of social production, liberating labor, mobilizing capital and modern technology, creating high productivity. Right after the founding of the country, He advocated: "Vietnam gives favorable reception to the investment of foreign capitalists and technicians in all its industries... Vietnam accepts to join all international economic cooperation organizations under the leadership of the United Nations" (Ho Chi Minh, 2021, vol. 4, p. 523). He guided the right path is the "path of national industrialization", opening the door to cooperation, creating great opportunities to build the nation and improve the people's living standards on the basis of production applied science and technology. The Government develops mechanisms and policies, establishes and maintains a system of economic management principles and creates levers to stimulate economic development, focusing on five economic sectors: State-owned economy; cooperatives; economy of individuals, farmers and craftsmen; private capital; State capital (such as the State co-operating with private capital for business) (Ho Chi Minh, 2021, vol. 8, pp. 293-294).

His ideology on economic development contains new, modern, scientific and revolutionary ideas, has topical significance and profound directional value in the process of economic construction and development in Vietnam today.

Fourthly, on culture and humanity.

From October 20 to November 20, 1987, at the 24th UNESCO plenary session in Paris, Resolution 24C/18.65 was issued to affirm: "Noting that the year 1990 will mark the centenary of the birth of President Ho Chi Minh, Vietnamese hero of national liberation and great man of culture,... Considering that the important and many-sided contribution of President Ho Chi Minh in the fields of culture, education and the arts crystallizes the cultural tradition of the Vietnamese people which stretches back general thousand years, and that his ideals embody the aspirations of peoples in the affirmation of their cultural identity and the promotion of mutual understanding" (UNESCO, 1987, p. 134). Ho Chi Minh left behind a comprehensive cultural value system, imbued with the spirit of the nation, humanity, democracy and science, aiming for truth - goodness - beauty.

From 1942-1943, he introduced the concept of culture: "For survival as well as the purpose of life, the mankind created and invented language, writing, morality, law, science, religion, literature, art, tools for daily living in terms of clothing, food, shelter and methods of use. All those creations and inventions are culture. Culture is the synthesis of all modes of living together with its expressions that mankind has produced in order to adapt to the needs of life and the requirements of survival" (Ho Chi Minh, 2021, vol. 3, p. 458). He considered culture to be both the goal and the driving force of the revolution, because culture is always oriented towards people and comprehensive human development. Culture - art is the spiritual life of society, belonging to the superstructure; culture - art cannot stand outside but must be in economy and politics; it must serve political tasks and promote economic development. He said: "1-Mental construction: independent and self-reliant spirit; 2-Moral construction: self-sacrificing, benefiting the masses; 3-Social construction: all causes are related to the welfare of people in society; 4-Political construction: civil rights; 5-Economic construction" (Ho Chi Minh, 2021, vol. 3, p. 458). Thus, cultural construction is carrying out a synchronous and comprehensive construction of mentality, morality, society, politics and economy.

His ideology on culture and humanity is a comprehensive value system that orients the construction and development of Vietnamese culture in order to affirm and uphold the right ideals and noble feelings of people; expand understanding, raise intellectual level; foster good and healthy qualities and styles, directing people to truth, goodness and beauty.

\subsection{The Sustainable Value of Ho Chi Minh's Morality for the Vietnamese People}

Firstly, on Ho Chi Minh's moral example.

Anyone who is virtuous, has a good heart, bright mind, high style, economic talent, and great will, that person cannot be without ambition. Ho Chi Minh is a man of great ambition. His ambition is not to be rich in material things, to eat well, to dress well, to have a house, a car, to have a wife and children, to have high power, etc., His 
ambition is "the desire, the ultimate desire which is to make our country completely independent, our people completely free, all compatriots have food to eat, clothes to wear, to be educated". Using the people's power, He entrusts Himself with the role of President of the Government and then President of the State to do great things for the people, country, and workers around the world. In His Will, He said his "last wish" was that "the entire Party, all our people unite to strive, to build a peaceful, united, independent, democratic and strong Vietnam, and to make a worthy contribution to the world revolutionary cause". During His whole life, He devoted himself to the long march of national liberation, social liberation, human liberation, not only for the Vietnamese people but also for the whole working-class humanity.

The entire career, life and morality of Ho Chi Minh is a natural expression, not forced, not arranged, is holy things, to direct towards good things, to convert to good, to exalt the beauty of people, and to foster conscientious people who always aspire to pure freedom in the institution of the universe. We find in Ho Chi Minh the beauty of Christianity, then the beauty of Buddhism, the eternal harmony of the universe of Taoism, the pearls of doctrines, of currents of thought, etc. Leader Ho Chi Minh has collected the values of absorbing Eastern, Western, modern and ancient civilizations, including the progressive thought of the French Revolution and the North American colonial liberation revolution, to enrich His intellect, creating values that elevate the times. As researcher Hélène Tourmaire affirmed: "Ho Chi Minh's image is complete with the combination of Buddha's wisdom, God's charity, Marx's philosophy, Lenin's revolutionary genius, and affection of the head of the family, all wrapped up in a very natural appearance" (Ho Chi Minh Institute, 1993, p. 109). But, His human nature is not the sum of those things, it is the synthesis, condensing them all into one, into a separate thing named Ho Chi Minh.

Secondly, on four ethical standards.

Ho Chi Minh has many explanations for the revolutionary moral standard that is to blend in with the masses into one mass, for the sake of the Fatherland and for the compatriots, good virtues such as humanity, righteousness, wisdom, courage and integrity will be multiplied in each person.

1) Loyalty to the country, Filial Piety to the people. "Loyalty" and "Filial Piety" are concepts of Confucian ethics, containing a narrow content "Loyalty to the king, Filial Piety to parents". He introduced into the old concept new content, which has scientific, revolutionary and humanistic significance. This is a revolution in moral conception. People from the status of slaves, without freedom, democracy became the master, creating history. Under the feudal system, mandarins were the parents of the people, under the new regime, the people are the masters, officials and party members are servants of the people. "Loyalty to the country, filial piety to the people" are the relationships that show responsibility for lifelong and whole-hearted action and determination to service to the revolution, the Fatherland, and the people; puts the interests of the Fatherland and the people first and foremost. Must firmly grasp the people's love, the people's mind, the people's will; care about civil rights, people's livelihood, people's wisdom, democracy, and civil mobilization; make the people believe, the people obey, the people love. That is really the new morality, the revolutionary morality.

2) Diligence, thrift, integrity, righteousness, impartiality are a measure of the civilization and progress of a nation: "A nation that knows Diligence, thrift, integrity, righteousness, impartiality is a nation rich in material things, strong in spirit, a civilized and progressive nation" (Ho Chi Minh, 2021, vol. 6, p. 128). It is the foundation of a new life, of patriotic emulation, a necessity to work, to be a human being, to be an official, to serve the union, class and people, the Fatherland and humanity. Diligence is to be hardworking, try to be resilient in the long process; be careful and reasonable planning. Thrift is to be thrifty, not luxurious, not wasteful, not indiscriminate; Thrift is not stingy, it means that the worth and beneficial work for the compatriots, for the Fatherland, no matter how much effort, how much money it costs, is also satisfied. Integrity is pure, not greedy for money, position, reputation, good food; cadres who rely on power to gouge people, bribe, and harm good people to maintain their position and reputation are all contrary to integrity. Righteousness is not evil, straightforward and righteous. Impartiality is an ethical quality that deals with the relationship with the public work, containing fairness and for the common good, not for self-interest, in the spirit of "taking care of the world first, being happy after the world". The practice of Impartiality is associated with anti-individualism. Individualism is a very poisonous germ that breeds hundreds of dangerous diseases such as embezzlement, wastefulness, bureaucracy, greed for fame, profiteering, love of position, power... Individualism is also a danger to the nation: "A nation, a party or a person was great, had great attraction yesterday, it is not sure to be loved and praised by everyone today and tomorrow if their heart is not pure anymore, if they fall into individualism" (Ho Chi Minh, 2021, vol. 15, p. 672).

3) Love for people. This is the moral quality that deals with relationships with others. Combining theoretical research with experiences, Ho Chi Minh believes that there are two types of people in this world: the oppressor 
and the oppressed, the evil person and the good person, and two things: the righteous deed and evil deed. He once said: My love for the people and humanity has never changed. I love the righteous deed and hate evil deed. Loving and cherishing people in Ho Chi Minh's ideology always turns into concrete actions, that is, human love for people who are living in this world, oppressed, poor, sick.

4) Pure international spirit. The international spirit is pure. President Ho Chi Minh was a fervent patriot, a great international soldier. He not only educated the pure and faithful international spirit, but also embodied the international spirit, combining genuine patriotism and proletarian internationalism. For more than half a century of revolutionary activities, He has always respected and cared for ethnic groups. He put the revolutionary cause of the Vietnamese people in the orbit of the world revolution; considered the victory of the Vietnamese people to be the common victory of the world's progressive people, and another country's victory is also our country's victory. "First of all, we must see that His contributions have contributed to deepening and developing the theory of Marxism - Leninism on national and colonial issues... The contributions of Ho Chi Minh really opened a new stage in national and colonial theories" (Singo Sibata, 1969). He condemned and fighted against division, hatred, inequality, racism; united with revolutionary and progressive forces around the world. He linked the struggle goal of the Vietnamese people with the common goal of mankind, which is national peace, independence, democracy and social progress. Ho Chi Minh's pure, loyal, consistent international spirit is an invaluable asset of the Vietnamese people, "He left His country a model of alliance building and a compromise that any modern state would appreciate." (Sophie Quinn Judge, 2002, p. 238).

Thirdly, on the three principles of ethical practice.

1) Cultivate morality throughout life. According to Ho Chi Minh, each person must voluntarily cultivate and practice morality associated with their actual life and work. He pointed out: "Revolutionary morality is not God-given. It develops and strengthens through daily struggle and practice. Just like the more jade is sharpened, the brighter it is, the more gold is refined, the clearer it becomes" (Ho Chi Minh, 2021, vol. 11, p. 612). Moral cultivation must come from each person's conscience, towards the goal of serving the Fatherland and the people. Without overcoming oneself, without defeating the "enemy in the heart", there can be no revolutionary morality. He wrote: "Communist ideology and individual thought are like rice and weeds. Rice must be fertilized very hard to grow well. And weeds that don't need to be taken care of also grow in abundance. Communist ideology must be practiced hard to achieve. And individual thoughts are like weeds, multiplying and proliferating very easily" (Ho Chi Minh, 2021, vol. 12, p. 222).

2) Moral example. Moral example is a beauty of Eastern culture, so Ho Chi Minh said that "for the peoples of the East, a living example is worth more than a hundred propaganda speeches". According to Ho Chi Minh's point of view, theory must be associated with practice, talking must go hand in hand with action, but the most morally important thing is to take efficiency as a measure. He pointed out that "in front of the masses, it's not like we keep using the word "communist" to be loved by them. The masses only like people who have moral character", being a example in many different environments and levels. People often say "Party members go first, people follow". In all exemplary performance, the leader and key cadres play a very important role. If we want to lead our subordinates and the people, we must set a standard for others to imitate.

3) Construction going hand in hand with prevention. This principle comes from scientific awareness that everyone may be good, evil and individualistic, that's the enemy in their hearts; In the social environment, there are always good and bad, positive and backward, that is the enemy outside. "Every enemy inside is an ally of the enemy outside. Enemy outside is not terrifying, enemy inside is terrifying, because it destroys from the inside out" (Ho Chi Minh, 2021, vol. 5, p. 278). Regardless of the circumstances, fighting the enemy and construction of new morality must go hand in hand, taking the example of good people, good deeds every day to educate each other and replicate advanced examples. In the relationship between prevention and construction, it is necessary to recognize that prevention also aims to construct, which goes hand-in-hand with construction, but construction is the main and long-term task to create a new morality in Vietnam, to build a new society with virtuous people.

\subsection{The Sustainable Value of Ho Chi Minh's Style to the Vietnamese People}

Ho Chi Minh's style reflects the core values of His ideology and morality which is expressed in a vivid, natural, unique, attractive, magical way in His daily activities and behaviors, forming a consistent whole with scientific, ethical and aesthetic values.

Firstly, independent, self-directed and creative thinking style.

For Ho Chi Minh, independence means not being dependent, not imitating, following, or dogmatic. Self-control is to actively think and control one's own thoughts and take responsibility for the nation. Creativity is the correct 
application of general laws to suit the individual and the particular things. At the same time, creativity is also exploring and proposing new things that can answer the demands of life. His newness and creativity are the ones that are consistent with the objective laws of the Vietnamese revolution and at the same time in line with the general development laws of human society. The newness can include the value of the old but surpasses, adds new value and has no historical precedent.

He has constantly studied, trained, received new knowledge on His own basis, not dissolved, imitated, dogmatic, conservative, but absorbed selectively, critically, not simply negated. Prime Minister Indira Gandhi (India) considered Him "a flexible, great and steadfast leader" (quoted by Evgeny Kobelev, 1995, p. 175). He constantly expanded his thinking, studies existing ideas and theories, success and failure experiences of the Vietnamese patriotic movement and other revolutions; always compared, choosed and found the new ones. He mastered the soul of Marxism-Leninism which is a materialist dialectic to creatively apply and develop revolutionary doctrine to the specific conditions of Vietnam. In order to have an independent, self-reliant and creative thinking style, all of Ho Chi Minh's thoughts are based on the reality of Vietnam associated with the changes of the world and the times as a starting point, taking the improvement of Vietnam's reality as the goal and properly reflecting the objective laws of history, so these ideas paved the way for the Vietnamese revolution to move forward.

In order to acquire, adapt, and form His own thinking style, He acquired, studied and distilled from many knowledges of the nation and humanity, He said: "Confucius's doctrine has the advantage of cultivating personal morality. The religion of Jesus has the advantage of great compassion. Marxism has the advantage of a dialectical working method. Sun Yat-Senism has the advantage that its policy is suitable to our country's conditions. Don't Confucius, Jesus, Marx, and Sun Yat-Sen have those things in common? They all want to "seek happiness for mankind, seek welfare for society. If they were still alive today, if they were to gather in one place, I believe they would definitely live together perfectly as close friends. I try to be their little student" (Vo Nguyen Giap, 1997, p. 93). With an independent and self-reliant thinking style, He demonstrated the following basic issues: Appreciating the position of the national liberation revolution in relation to the proletarian revolution; properly dealing with ethnic and class relations in the national liberation revolution; properly identifying revolutionary forces and building class alliances in the national liberation revolution; successfully building a Marxist political party in an underdeveloped colonial country.

Secondly, scientific, democratic, mass working style.

Ho Chi Minh has a working style of mass, collective, democracy, science, closely linked together, forming a very modern working style.

1) Scientific working style. Ho Chi Minh asked each person in charge: to "approach deeply, approach closely, investigate, research" to grasp work, know people and understand specific situations; have a clear and focused purpose; The planned program must be consistent; check the performance of subordinates and the masses; be specific, timely, practical, focused, and typical; practice the style of "thinking, looking, hearing, walking, talking, doing at the same time", be careful and agile in time, do right. He criticized "the impractical working, not from the main thing, not from small to big, working superficially, working a little but reporting a lot to show off but empty" (Ho Chi Minh, 2021, vol. 5, p. 297). Must regularly pay attention to learn from experience, summarize failed practices and successful experiences to disseminate to all officials and localities. "Each cadre, each locality will learn from good experiences, avoid bad experiences, and apply old experiences to new jobs" (Ho Chi Minh, 2021, vol. 6, p. 238). Ho Chi Minh is the exemplary model of the style of "the master strategist, veteran revolutionary of Vietnam" (William J. Duiker, 2000, p. 3).

2) Collective and democratic working style. Being the head of the ruling party, the head of the democratic state, at the peak of power, but sticking to the collective, respecting the collective, promoting strength of the collective is the guiding principle of Ho Chi Minh's thoughts and actions. Many times, he criticized the leadership of some undemocratic cadres, leading to people who have opinions but "don't dare to speak, they are afraid", people who want to criticize do not dare to speak. He always requires the leaders to have a truly democratic collective style, to seek and respect everyone's opinions, regardless of position or rank. Because every pretense weakens, even breaks down the collective, every formalism will sooner or later erode or even destroy democracy.

3) Mass working style. This is the most important content of Ho Chi Minh's working style, which is expressed by specific actions: Closing to the masses, "revolving around respecting the people, paying attention to the needs of the people" (Song Thanh, 2010, p. 361), listening to the thoughts and aspirations of the people. Believing in the people, dealing with the people's legitimate recommendations, being ready to accept the people's criticisms and promptly correcting the defects and shortcomings. Educating and leading the masses, and at the same time constantly learning from the masses, respecting the mastery of the masses in the spirit of cadres who are both 
leaders and loyal servants of the people. Having to be an example to be worthy of the people's trust. The mass style made Ho Chi Minh and the people, the leader and the masses integrated, simple, natural and deeply empathetic. People can say all their thoughts and concerns to the leader, while the leader can hear and understand what life is demanding and expecting, as the Korean professor commented: "I think that in the future world leaders need to accept the spirit of President Ho Chi Minh so that their country will be good and their people will be happy" (Ahn Kyong Hwan, 2011). Mass behavior is necessary not only for the relationship between cadres and people, but also for the relationship between cadres and cadres, superiors and subordinates. This is political art and political prestige indispensable for any leading organization.

Thirdly, the modest, polite, sincere, warm, natural, and flexible behavior style.

Behavior is a way of communicating, treating people to people, between individuals and the community, behavior is not only expressed through words, gestures, facial expressions but mainly in the sincerity of feelings and of the relationship between the subject and the object.

In interactions, $\mathrm{He}$ is usually humble, never putting Himself higher than others, on the contrary, He is always gentle and caring for those around Him. Wherever He went, He also paid attention to visit famous people, intellectuals, elders, women's representatives and respectfully invited them to sit on top, showing an elegant, very Asian style. Welcoming guests at a hotel in Paris in 1946, Ho Chi Minh shook hands with people, talked intimately, very naturally, accompanied by compliments and praises to France... The French were very sympathetic to Him. Therefore, the President of Chile replied to the journalists about the three qualities of a political activist that He wanted to have: "Ho Chi Minh's consistency, humanity, and humility" (Salvador Allende, 1971).

When meeting people, with intimate gestures, sincere greetings, or a joke, He created an atmosphere of intimacy, comfort, closeness like in a family. He always showed cheerfulness along with a diverse and rich sense of humor which erased the dividing wall, unnecessary formal rituals, and created a harmonious and close atmosphere between the leader with the masses and with friends, etc. That explains why every time He appeared, there was a burst of joy and endless laughter. The outstanding features in His communication and behavior are sincere humility, genuine friendliness with people, kindness, warmth, erasing all rituals, going straight to people's hearts with genuine and natural feelings, that is the highlight of the behavior style of great culturalists of all time.

Fourthly, the simple, clean, moderate, and moderate living style.

Ho Chi Minh has a lifestyle that shows simplicity, purity, highness, moderation, orderliness, love of labor, and respect for time. It is also the love of people mixed with the love of nature, creating the optimistic spirit of the soldier combined with the vibration and passion of an artist's soul. It is true that He "has an ethereal life, without any privacy, always respects principles, has faith in truth and justice" (Song Phil - Kyung, 2020, p. 53).

He had a diverse and rich everyday life. He lived the life of a craftsman, a sailor, a writer, a journalist, a teacher, a student, a soldier in the war, a revolutionary soldier operating in secret, a prisoner, a statesman, a diplomat and a head of state for many years. Regardless of what life and how He lived, His lifestyle still remained true to the principle: taking humility and simplicity as the foundation, taking moderation as the standard, taking purity and highness for joy, and taking attachment between man and nature as an endless passion. As assessed by Nguyen Dai Trang, a lecturer at the University of Toronto Scarboroug, "Virtue and talent created Ho Chi Minh's success" (Nguyen Dai Trang, 2010). His living style became complete, with a full life from the moment He entered the world to the eternity.

\section{Conclusion}

The world and the country of Vietnam are changing, constantly progressing and civilized, but the values of Ho Chi Minh's ideology, morality and style are immortal over time. Ho Chi Minh's legacy is revolutionary, scientific and empirically tested to be true in the history of the Vietnamese nation and has universal significance today. The article "The value of Ho Chi Minh's ideology in the current era" by Theshom Kebede affirmed that "the theoretical views of Ho Chi Minh and His ability to creatively use historical and materialistic methods to solve social phenomena are the source of his brilliant ideology. His ideology has been tested in the specific conditions of Vietnam, opening up unprecedented potentials for national liberation movements" (NCSH, 1995, p. 88). Ho Chi Minh's ideology has been recognized as the ideological foundation and guideline for all actions of the CPV, the armed forces and the Vietnamese people. Leader Ho Chi Minh is a shining example of patriotism, love for the people and the spirit of struggle against oppression and exploitation. He has the moral qualities of Diligence, thrift, integrity, righteousness, impartiality and a pure international spirit that throughout His life He cultivates, trains and persists. Through revolutionary activities and contacts, it is easy to see that Ho Chi Minh has typical 
and unique style in terms of thinking style, working style, behavior style and lifestyle. This article is researched from the scientific point of view and the theoretical - practical value level, clarifying the basic meaningful features and affirming the vitality of Ho Chi Minh's ideology, morality and style for the Vietnam nation. His legacy is crystallized from the good values of humanity, representing the vision of the times and a symbol of global citizenship.

\section{References}

Ahn, K. H. (2011). Interview with Professor Ahn Kyong Hwan on Propaganda Magazine, Vietnam. Retrieved from https://tuyengiao.vn/theo-guong-bac/ho-chu-tich-trong-an-tuong-cua-giao-su-han-quoc-31464

Charles, F. (1970). Ho Chi Minh, Notre camarade. Sociales. Pari. p. 29.

Christopher, W. P. (2010). 'Vietnam: It's Our War Too:' The Antiwar Movement in Canada: 1963-1975. This thesis, dissertation or report is accepted by the Dean of Graduate Studies the University of New Brunswick. Published Heritage Branch. 395 Wellington Street Ottawa ON K1A0N4 Canada. September 2010. p. 133. Retrieved from https://central.bac-lac.gc.ca/.item?id=NR87683\&op=pdf\&app=Library

Communist Party of Vietnam (CPV). (2021). Document of the 13th National Congress. National Truth Political Publishing House, Hanoi.

Evgeny, K. (1995). Ho Chi Minh - a patriot, a revolutionary and a man, in the book of the National Center for Social Sciences and Humanities of Vietnam (NCSH) - Vietnam's National Commission for UNESCO. President Ho Chi Minh - National Liberation Hero, Great Man of Culture, Social Sciences Publishing House, Hanoi. p. 175.

Ginbe Hanđátsơ. (1970). Ho Chi Minh - an excellent theorist on colonialism and the national liberation movement. Planet - Action Magazine. Paris, March issue.

Ha Binh Nhuong. (2000). Compassionate heart. Writers Magazine of the Vietnam Writers Association, (3), 20.

Ho Chi Minh Institute. (1993). Ho Chi Minh lives forever in the hearts of mankind, Labour Publishing House People's Army Publishing House. Hanoi. p. 109.

Ho Chi Minh. (2021a). Complete volume, volume 2. National Truth Political Publishing House. Hanoi.

Ho Chi Minh. (2021b). Complete volume, volume 3. National Truth Political Publishing House. Hanoi.

Ho Chi Minh. (2021c). Complete volume, volume 4. National Truth Political Publishing House. Hanoi.

Ho Chi Minh. (2021d). Complete volume, volume 5. National Truth Political Publishing House. Hanoi.

Ho Chi Minh. (2021e). Complete volume, volume 6. National Truth Political Publishing House. Hanoi.

Ho Chi Minh. (2021f). Complete volume, volume 8. National Truth Political Publishing House. Hanoi.

Ho Chi Minh. (2021g). Complete volume, volume 9. National Truth Political Publishing House. Hanoi.

Ho Chi Minh. (2021h). Complete volume, volume 10. National Truth Political Publishing House. Hanoi.

Ho Chi Minh. (2021i). Complete volume, volume 11. National Truth Political Publishing House. Hanoi.

Ho Chi Minh. (2021j). Complete volume, volume 12. National Truth Political Publishing House. Hanoi.

Ho Chi Minh. (2021k). Complete volume, volume 13. National Truth Political Publishing House. Hanoi.

Ho Chi Minh. (20211). Complete volume, volume 15. National Truth Political Publishing House. Hanoi.

International Conference, President Ho Chi Minh - National Liberation Hero, Great Man of Culture. Social Sciences Publishing House. Hanoi. 1990.

Lacouture. (1967). Ho Chi Minh.. Ed.Seuil. Paris. p. 200.

Nguyen Dai Trang. (2010). Ho Chi Minh - The Virtue and Talent of a Patriot. National Political Publishing House. Hanoi.

Nhan Dan newspaper. (1965). No. 4062. May 18.

Romesh Chandra. (1980). Ho Chi Minh in the heart of humanity. Nhan Dan Newspaper. May 21.

Salvador Allende. 1971). Answered as follows to a journalist's question: "What are the three qualities of political activists that you would like to have?", Propaganda Magazine, Vietnam. Retrieved from https://tuyengiao.vn/theo-guong-bac/ho-chi-minh-nguoi-la-nguon-cam-hung-muon-doi-127958

Sin-gô Si-ba-ta. (1969). Ro-ki-xi Hy-o-rong magazine, No. 232, Tokyo, May issue. 
Song Phil - Kyung. (2020). Why Ho Chi Minh? National Truth Political Publishing House. Hanoi. p. 53.

Song Thanh. (2010). Ho Chi Minh - Great Man of Culture. National Political Publishing House.

Sophie Quinn Judge. (2002). Ho Chi Minh's wandering years (1919-1941). University of California press. p. 238.

The National Center for Social Sciences and Humanities of Vietnam (NCSH) - Vietnam's National Commission for UNESCO. (1995). President Ho Chi Minh - National Liberation Hero, Great Man of Culture, Social Sciences Publishing House, Hanoi. p. 28-29.

UNESCO: unesdoc.unesco.org/images/0007/000769/076995e.pdf, p. 134.

Vo Nguyen Giap. (1997). Ho Chi Minh ideology and Vietnam's revolutionary path, National Political Publishing House. Hanoi. p. 43.

William, J. D. (2000). Ho Chi Minh a life. New York Hyperion Publishing House.

\section{Copyrights}

Copyright for this article is retained by the author(s), with first publication rights granted to the journal.

This is an open-access article distributed under the terms and conditions of the Creative Commons Attribution license (http://creativecommons.org/licenses/by/4.0/). 